\title{
Problematizing Critical Theory: Arriving at a More Critical Critical Theory
}

\section{Agustin Martin G. Rodriguez}

\begin{abstract}
This paper reflects on how critical theory is deeply rooted in Western, European philosophical traditions. It argues that a more radical critical philosophizing could be realized if the rationality of the othered traditions of thinking are brought to bear in critical theorizing.
\end{abstract}

Keywords: Habermas, critical theory, Filipino thought, discourse theory

7 here is a style of philosophizing in the Philippines that is rooted in the Critical Theory school of thought. This tradition focuses its research on the critique of Philippine socio-economic realities using the methods of ideology critique applied to mass society, Westernization, neo-Liberalism, and the market economy. This philosophical tradition has been very useful in recognizing the complexities of consumerism, multiculturalism, globalization, and postcolonial struggles for self-determination. In most of our philosophical conferences, critical theorists are very present as guides for interpreting our societies and the problematic lives we build in these postmodern, postcolonial, and postmetaphysical epoch. Because of this tradition, Filipino scholars have been given a tool with which they can expose the underlying ideological and structural substructures that frame the suffering of the people and, with it, imagine possible paths of development and liberation.

If one reviews the research of Filipino scholars, one will see many works that critique Philippine social systems exposing the ideological frames that determine the dynamics of governance, policy making, sexual politics, multicultural co-existence, and economic development. They pose questions regarding the rationality behind development, the definition of good governance by Western values, and the roots of poverty in power relationships. But mostly, the works are applications of ideology critiques on Philippine social realities. For instance, they will show how elections do not

(c) 2019 Agustin Martin G. Rodriguez

https://www.kritike.org/journal/special issue/rodriguez april2019.pdf

ISSN 1908-7330 
fulfill the fundamental criteria for genuine discourse. They will discuss how poverty is a failure of solidarity or the blind adherence of government institutions to the illusion of free markets as free. They show how the insurgencies we face can be responded to more effectively with a clearer critique of the interests that define that discourse of peace. Many of these papers would take the form of a Habermasian critique of the peace process or an ideological critique of the ASEAN consolidation process. Thus, critical theory has been a useful tool for the critique and reform of the Philippine nation-state which aims to realize genuine democratization and development. Critical theory has an effective way of giving a thinker a tool for digging more deeply into the rationalities that shape society and bind people to exploitative structures. However, given that the tools used to critique the ideologies that frame us are themselves framed by the Western (perhaps even modernist) minds that framed these very same ideologies, our critical theories may lack what they profess to offer us, i.e., the deep critique of society that unearths the ground supporting the naiveté of Western man's global world-building. What do I mean by this? Let us look at one of the most important and most useful scholars of critical theory, Jürgen Habermas.

\section{A Brief Discourse on Discourse Theory}

Habermas is arguably one of the most influential critical theorists. He studied some of the most problematic realities of postmodernity and offered a way - founded on justice and solidarity - to confront them. One of his main questions was the possibility of building a shared conception of the good in post-traditional societies. ${ }^{1}$ In the postmodern situation, when the West woke up to the reality that theirs was not the only (albeit still the superior) rationality, they began to question the possibility of having a shared conception of the good in a multiplicity of rationalities. In the late $20^{\text {th }}$ century, as the world turned more radically global, the Western world realized that there were other possibly legitimate rationalities than the dominant male, abstract, systematic system of meaning-giving. This was the time of the assertion of the woman's way of knowing and the postcolonial discourses of the colonized others. This was the time of the other when Western civilizations were being questioned for their totalizing orientations by their own thinkers. It was the time when the West began to question its naïve belief that their rationality bore a universal ground for the good, the authentically rational. How can humanity come to a shared conception of the good when the legitimacy of White, male rationality was so clearly losing its legitimacy?

\footnotetext{
1 Jürgen Habermas, "The European Nation-State: On the Past and Future of Sovereignty and Citizenship," in The Inclusion of the Other: Studies in Political Theory, ed. by Ciaran P. Cronin and Pablo De Greiff (Cambridge: The MIT Press, 2001).
}

(c) 2019 Agustin Martin G. Rodriguez https://www.kritike.org/journal/special issue/rodriguez april2019.pdf ISSN 1908-7330 


\section{A MORE CRITICAL CRITICAL THEORY}

This was, after all, the era of the great wars, and a time when the abuses of the great systems of Western totality-capitalism and colonialism-were causing destruction and misery on a global scale.

This is the background for the need for the development of a critical theory that addresses the radical roots of the oppressive dominant system. Habermas addressed the problem by proposing a discourse theory that allows a multi-rational society to come to a shared conception of the good. ${ }^{2}$ In a particularly profound analysis of communicative practice in terms of lifeworld and systems, he explained how, in praxis, dominant systems that shape our ways of seeing and being in the world are formed. ${ }^{3} \mathrm{He}$ also showed how, through discourse, societies can collectively critique their defining ideologies and justly come to a shared will- and opinion-building societal process that will ensure solidarity among citizens. ${ }^{4}$ Habermas's theory is important because it shows both how to critique the dominant system of which we may not even be aware, and how ways of collectively and critically building an ideology can bind autonomous, rational, and free individuals.

The discourse ethics procedure that Habermas formulated is precisely founded on the understanding that human beings are autonomous rational beings who are capable of legislating a shared conception of the good for themselves. ${ }^{5}$ Given this fundamental capability, procedures for discourse need to be formulated to give these autonomous lawgivers a structure for fair processes of legislation. ${ }^{6}$ These procedures allow for the creation and maintenance of an arena for encounter of rational minds in order to share their deepest convictions and mutually critique each other's understanding. These procedures ensure that all persons are allowed to fairly express their conceptions of the good to each other in such a way that all the participants in fair discourse are able to examine the limitations of their own and each one's particular conceptions. However, one wonders if Habermas's assumptions about fair discourse are themselves critical enough. The basic assumption of Habermas is that the person most capable of building a multirational society is autonomous and rational in the Western mode. What does this Western mode of autonomous personhood mean?

\footnotetext{
2 Ibid.

${ }^{3}$ The analysis is particularly thorough in his masterwork. See Jürgen Habermas, The Theory of Communicative Action I, trans. by Thomas McCarthy (Boston: Beacon Press, 1984).

${ }^{4}$ Jürgen Habermas, Between Facts and Norms: Contributions to a Discourse Theory of Law and Democracy, trans. by William Rehg (Cambridge: The MIT Press, 1999).

5 Jürgen Habermas, "Discourse Ethics: Notes on a Program of Philosophical Justification," Moral Consciousness and Communicative Action, trans. by Shierry Weber Nicholsen and Christian Lenhardt (Cambridge: The MIT Press, 1990).

${ }^{6}$ Ibid. See also Jürgen Habermas, "Remarks on Discourse Ethics," Justification and Application: Remarks on Discourse Ethics, trans. by Ciaran P. Cronin (Cambridge: The MIT Press, 1993).
}

(c) 2019 Agustin Martin G. Rodriguez

https://www.kritike.org/journal/special issue/rodriguez april2019.pdf

ISSN 1908-7330

(cc) BY-NC-ND 
The rational, Western man is a person who exists primarily as an individual capable of coming to knowledge using his own, personal reasonwhich he can check against the understanding of others. This person is confident that his use of reason will give him a workable understanding of the world because reason has processes of self-verification. Reason has a way of validating its understanding of the world by ensuring that all insights into the real are acceptable to its established systems of meaning-giving based on its categories of understanding. This is useful because although others may have a different understanding of the world, these various conceptions of reality are reconcilable because fundamentally they are founded on the same systems of meaning formation. I suspect that each person is thought to be capable of coming to a shared conception of the good because they share the same categories of understanding and that the use of these categories can be disciplined and universalized, as we have in science, to allow for a shared opinion and will formation. This is why Habermas's main concern for fair, solidarity-building discourse is procedural. The autonomous lawmaker worthy of Habermasian discourse is the bearer of Kantian rationality-the person who knows that the key to understanding the world is the proper or disciplined use of self-verifying reason.

The value of Kant as an epistemologist is that he was able to explain that the knowledge of pure reason was founded on the application of the categories of reason to the data of the sensibilities which use their own forms. He showed that all human beings know the world based on universal, a priori structures and that all human knowing is universalizable once we agree on how the categories are validly applied to data. The same is true for the use of practical reason. Although there are no indubitable grounds for determining the good, it is possible to determine conceptions of the good that are acceptable to reasonable persons as rational. This is why the formulation of the Kantian conception of the good is to formulate a maxim that one can legislate for all rational people. For Kant, it is possible to come to a universal conception of the good that is valid if people use their reason in a way that is in accord with reason's capacity to articulate and understand the good. With the maxims of practical reason, one does not necessarily come to an understanding of the good in an ontological sense. Rather, one comes to a conception of the good that reason can accept as reasonable. The autonomous lawmaker can legislate for himself the good because he bears reason and reason determines what is acceptable as good.

The autonomous lawmaker is a person who can rely on his rationality to formulate a conception of the good that does not need an ontological grounding, but only a form that reason itself can validate. Thus, the focus on a valid understanding of the good and a valid knowledge of the world is rooted in the proper use of reason such that it can validate itself. It is not 


\section{A MORE CRITICAL CRITICAL THEORY}

necessary for the autonomous lawmaker to be able to know the good or the true. It is unnecessary for this person to be rooted in the presencing of beings as they are given to presence. This autonomous lawgiver is not intuitively connected to the world as a unified cosmos because autonomous reason means an independence from any transcendent order. The possibility of having an autonomous lawgiver spells the freedom from the idea that the world has a transcendent order and that genuine human knowing is the opening to the transcendent order. The autonomous person is the bearer of the structure of knowing using his reason alone. Meaning is constructed by that reason and its systems independently of a belief that the world is a bearer of its own meaning.

Discourse theory proceeds from the understanding that rational persons construct the good as a maxim that all persons of good reason can abide by. The good is agreed upon not because it reflects the world as it presences but because it is acceptable to all persons capable of rational discourse. In this way, the fair system of discourse becomes oriented toward a building of society based on the rationality of autonomous, rational (a.k.a. Western) men. Habermas, without stating it, already legitimizes Western, male rationality and delegitimizes the other rationalities especially those who are known as traditional, tribal, or metaphysical. This is because he places as the higher rationality that of the autonomous, male thinking rooted in the abstract thinking of pure and practical reason that tend to accept as legitimate scientific forms of reasoning abstracted from a meaningful cosmos. Immediately, and unconsciously, this places the Westernized rationality on a level superior to what Habermas regards to be the metaphysical or traditional rationality.

This is the reason why, whenever Filipino scholars apply discourse theory perspectives to political reform in the Philippines, their prescriptions are always oriented toward the implementation of systems of discourse that favor Western-educated rationalities. This can be seen in their critical view of "the masses," "the uneducated," and "traditional peoples" who are unable to participate in rational discourse, as well as the uncritical critiques of patronage politics and traditional forms of community formation. Rational discourse here means discourse that favors data-based, argumentative, agonistic thinking where claims to truth are only accepted when substantiated by grounds acceptable to systematic, abstract, and scientifically framed justification. In other words, the only acceptable claims to legitimacy are claims that are supported by the ways of thinking of Kantian rationality. Thus, most philosophical reflections on political, electoral, and economic reform in the Philippines tend to believe that empowerment of the margins will only genuinely be realized when the disempowered are educated in the

(c) 2019 Agustin Martin G. Rodriguez

https://www.kritike.org/journal/special issue/rodriguez april2019.pdf

ISSN 1908-7330

(c) ) BY-NC-ND 
ways of Western democratic deliberation. Thus, our focus as reformers is always on our people's education in citizenship.

Take the Kapit-Bisig Laban sa Kahirapan-Comprehensive and Integrated Delivery of Social Services (Kalahi-CIDSS) program of the Philippine government as an example. ${ }^{7}$ This massive anti-poverty program meant to fund effective development projects in the poorest Filipino communities is designed to introduce grassroots leaders to effective participatory project identification, proposal, and implementation. Toward this end, teams from the Department of Social Welfare and Development (DSWD) are sent to the poorest barangays to coach them in participatory poverty mapping and project identification and implementation programs. The brilliance of the Kalahi-CIDSS design is that it is meant to bring development to the poorest barangays through participatory, empowerment techniques. Through the coaching of the DSWD, the grassroots leaders and other members of marginalized communities - whose rationalities are unable to navigate the dominant rationality-are allowed to understand their development issues from their perspectives, then, are taught how to translate their concerns to the development goals of the national government, that is, from issues regarding income generation, basic services, and security, into terms that funding agencies can accept as worthy of support.

From one perspective, this is a development program worthy of Habermasian discourse theory. Firstly, it allows people from marginalized rationalities to effectively and creatively engage the dominant rationality by creating structures and systems for discourse. Secondly, it teaches them to think about their problems within the framework of the dominant conception of development. The Kalahi-CIDSS program is designed to allow for discourse toward liberation. It allows for a people who are caught in oppressive systems to critically engage the marginalizing system in order to make it more responsive to their needs. However, the discourse system still insists that the liberating discourse occur within the framework of the dominant rationality. Fundamentally, the program aims to teach the marginalized rationality to discourse with the dominant rationality on the dominant rationality's own terms. Thus, its conception of the good, its understanding of development, and its definition of human flourishing will all occur within the dominant system. This framework for liberation, without realizing it, effectively entrenches the marginalized rationality firmly in the dominant. The Kalahi situation does not stand as a metaphor for the limits of the liberation work of discourse theory. Rather, it is the concrete

7 Asian Development Bank, The KALAHI-CIDSS Project in the Philippines: Sharing Knowledge on Community-Driven Development (Mandaluyong City: Asian Development Bank, 2012), <https://www.adb.org/sites/default/files/publication/ 29878/kalahi-cidss-projectphilippines.pdf $>$.

(c) 2019 Agustin Martin G. Rodriguez https://www.kritike.org/journal/special issue/rodriguez april2019.pdf ISSN 1908-7330 


\section{A MORE CRITICAL CRITICAL THEORY}

demonstration of how the naiveté of critical theory can deepen marginalization.

Kalahi-CIDSS is an anti-poverty program designed around discourse. People are supposed to be liberated from their marginalization through processes which allow them to creatively and effectively engage the dominant rationality and its governance systems for their development. Communities are taught to think within and discourse with the dominant system. Eventually, their own rationalities will be aligned to the dominant system because they will realize that as long as they can frame their problems within the dominant discourse, then they can effectively access resources for their development-development which is itself framed by the rationality of the dominant system. Because of this, the marginalized are assimilated into the hegemonic discourse of Western development. In effect, the multiplicity of rationalities would be reduced to the powerful totality of the dominant development thinking. And so, the system that was meant to liberate people through discourse facilitated their absorption into the dominant system, in a sense, facilitating their exploitation as low-cost producers and laborers as well as consumers. Thus, because of its failure to question the dominance of the dominant rationality, this seemingly innovative practice based on the principles of empowerment and liberation can achieve a purpose that counters its avowed objective.

I believe that it is possible that in the philosophical and the broader academic arena, our critical theory lenses uncritically contribute to the Westernization of the world. This is because critical theory, being a child of the Western fin de siècle crisis, is really oriented toward the critique of the shortfalls of Western rationality in order to reform it and make the Western world more critically rational. However, the fundamental faith in Western rationality was never abandoned. In order to genuinely critique the unchallenged, dominant Western rationality, we must begin to explore the legitimacy of other rationalities that themselves make alternate truth claims founded on other forms of reason for the very reason that we need to explore the possible fruitfulness of other forms of rationality.

Our tasks as adherents of critical theory is to embrace its mission of ideology critique and push it further by even more radically grounding our critique of society on other grounds. Of course, the only truly radical ground of ideology critique is the transcendent rationality that is not influenced by any ideology. However, there is no such human perspective. The best we can do is to explore the grounds of legitimacy of other claims to truth and place them in just and equal discourse with the dominant rationalities. In our case, this concretely means exploring indigenous, non-Western rationalities which could enrich the discourse on the good. The only way to genuinely critique one's rationality is if there is another perspective that challenges the very

(c) 2019 Agustin Martin G. Rodriguez

https://www.kritike.org/journal/special issue/rodriguez april2019.pdf

ISSN 1908-7330

(c) $)$ BY-NC-ND 
ground of our assumptions. So far, the West has only dialogued with itself and with its junior partners who could only join the discourse if they fit their own rationalities to the forms acceptable to the dominant culture.

\section{Researching Otherwise}

In the Philippine context, it has always been easier for local thinkers to engage the mainstream discourse of our discipline if we tailor our social analysis to dominant paradigms of thinking: Marxist, ideological critique, feminist theory, postcolonial criticism, and deconstruction. The reason is because we have not been able to demonstrate the ground of legitimacy of our own indigenous forms of inquiry. There are too few studies that explore how indigenous rationalities present a rigorous frame for reading social phenomenon. In order to explore the legitimacy of indigenous discourse, we must promote studies that do not merely translate or justify the native in terms of the dominant rationality. Rather, we must articulate these rationalities in a way that demonstrates the value of their forms of knowing on their own terms. These studies must have rigor in the sense that they can legitimately articulate the play that brings these systems of understanding their structure and dynamism. We must have studies that are not just an interpretation of other rationalities in the mode defined as legitimate by the dominant academic rationalities. Rather, we must engage these rationalities in a way that allows the rationality to demonstrate its own ways of meaninggiving in order for others and even the adherents of that rationality to recognize how it gives meaning to the world that presences. These alternative meaning-giving systems could allow for the most authentic critique of the dominant rationality which critical theory fundamentally seeks to realize. This is because the only way any society can come to a critical understanding of its dominant systems is if it is able to dialogue with a rationality that can genuinely question its most basic premises. Thus, if our philosophy practitioners are to genuinely contribute to critical theory, such contribution will be realized in our ability to bring our native rationalities into critical dialogue with the dominant systems.

There have been some notable attempts at this kind of work. I would like to cite here the works of Zeus Salazar and Reynaldo Ileto in history, Virgilio Almario in literature, and Grace Nono in ethno-musicology. Let us begin with Salazar. Among Salazar's notable works is his Ang Kartilya ni Emilio Jacinto. ${ }^{8}$ Here he argues against the thesis that the ideology of the Katipunan is a mere indigenization of the liberal ideals of the French

8 Zeus Salazar, Ang Kartilya ni Emilio Jacinto at Ang Diwang Pilipino sa Agos ng Kasaysayan (Quezon City: Palimbag ng Lahi, 1999). 


\section{A MORE CRITICAL CRITICAL THEORY}

Revolution and the European Enlightenment. He shows how the fundamental ideals of kalayaan, katwiran, and kapatiran are indigenous ideas that do not merely translate European ideals but rather articulate a fundamental conception of reality. Salazar, through a genealogy of words and their evolution shows how the Filipino conceptions of a good society worth fighting and dying for have a nuance that puts into question the kind of societies toward which we believed the Katipunan should have been building. Ileto's classic, Pasyon and Revolution, is a work that shows how the revolutionary aspirations of the people are rooted in the Pasyon rationality. ${ }^{9}$ It explores how the indigenous interpretations of Langit was the foundational idea of a kaharian or bayan that inspires many of our grassroots revolutionary movements. He showed how the Filipinos appropriated the colonizing, Catholic narrative as a discourse of liberation for the marginalized natives. ${ }^{10}$ These historical studies, mostly accomplished in the Western mode of postmodern scholarship of suspicion, reveal a hidden rationality written over by the dominant, official history. They expose the palimpsests in the imposition of Western rationalities. In so doing, they give us a glimpse of the alternate rationality that defined the indigenous people's conception of the good, and showed how a recognition of this rationality thus imposed can become a ground for a radical critique of the dominant world order.

Almario is pursuing a seemingly similar project in his multi-study opus of literary criticism. In his reading of the classics of Philippine literature, including the novels and poems of Rizal, Florante at Laura, the foundational Tagalog novels, and the literary production of the revolutionaries of 1896, particularly the work of Andres Bonifacio, he shows how these works of literature were misjudged by previous scholars because they insisted on reading the works from an American or European aesthetic and academic framework. He labors to show the dynamism of intersecting traditions and historical circumstances that bring about these works. Concretely, he illustrates how these works were demeaned by scholars trained in Western traditions and how the works demand their own categories of appreciation than those established for Western works. ${ }^{11}$ In this way, Almario argues for a native literary practice that is rooted in the lived experience of the people. He shows that the works of the literary tradition generate their own aesthetic categories rooted in the dynamic play that produces these works. He shows us that if people desire to genuinely understand the contribution of Filipino Press, 1979)

${ }^{9}$ Reynaldo Ileto, Pasyon and Revolution (Quezon City: Ateneo de Manila University

${ }^{10}$ Ibid.

11 Virgilio Almario, "Mga Bukal at Batis ng Nobelang Tagalog: Panimulang Suri," Unang Siglo ng Nobela sa Pilipinas (Manila: Anvil, 2009). Similar insights can be found in Virgilio Almario, Ang Pag-ibig sa Bayan ni Andres Bonifacio (Manila: UST Publishing House, 2012).

(c) 2019 Agustin Martin G. Rodriguez

https://www.kritike.org/journal/special issue/rodriguez april2019.pdf

ISSN 1908-7330

(c) $)$ BY-NC-ND 
literature to world literature, they must enter the dynamic rationality that produced it and its understanding of the world and the good.

These scholars have shown us how to critically think about the dominant systems of reading history and works of literature. They help us understand that other methods are needed to understand the artifacts and traces of our other rationalities, and how the dominance of Western rationalities, as reductive frames for interpreting our acts and artifacts, need to be challenged. They challenged these enframing frames of interpretation by producing critical works that made their native readers aware that they saw the world from other rationalities that needed to be articulated in order to appreciate their understanding of the good despite their being imposed upon by the dominant Western conceptions. These studies are useful in understanding how to critique dominant systems of rationality and how these dominant systems are still applied to demean our otherness. However, these local scholars' own methods are still accomplished within the frame of the dominant rationality. Fundamentally, the otherness of the Philippine novel and the ideology of the revolution were articulated in Western forms of abstraction and systematization. The other was fundamentally translated for the analytic gaze of the dominant mind.

Grace Nono's work shows us a step further in the exploration of the native conception of the world. In her work of ethno-musicology, Song of the Babaylan, ${ }^{12}$ she shows us how research on the babaylan culture demands a different form of research, a different methodology. For her, it is important to engage the babaylan cosmology with a different method of research because we wish to faithfully speak of another way of knowing another world. It is an other of the systematic rationality of the West, and we do not merely want to translate this other rationality for consumption by Western systems of comprehension. Thus, other categories of understanding and articulating are needed.

How does one do research in a setting where the people about whom one is learning are dwellers in a completely different rationality and in effect belong to another world? It seems that the only way of genuinely engaging this world and its presencing is through an immersion that fully opens to its rationality and its modes of presencing. It is not an immersion that prioritizes the desire of reducing this world's presencing to abstract, conceptual systems and the reduction of its lifeworld to the abstract systems of modern rationality. Rather, the aim would be to focus on pakikipagkapwa as a mode of research. This aims less at abstract systematization and more at a deeper understanding that reaches the levels of sympathetic understanding. It is a kind of understanding where we understand the other reality but with the

${ }^{12}$ Grace Nono, Song of the Babaylan (Quezon City: Institute of Spirituality in Asia, 2013).

(c) 2019 Agustin Martin G. Rodriguez https://www.kritike.org/journal/special issue/rodriguez april2019.pdf ISSN 1908-7330 


\section{A MORE CRITICAL CRITICAL THEORY}

insight of one who is able to enter the world of the other even if one is other than them. Thus, techniques of pakikipagkapwa or entering the world of the kapwa as a sympathetic other need to be applied. ${ }^{13}$

According to Nono, these are the possible research tools to use. Pakigambit or the reciprocity of sharing one's self by spending time with the other is a sharing in the life of the other in an opening to presence and being present. This sharing of self does not allow for the best form of systematic abstraction that would lead to useful knowledge. However, it allows for the thinker to be immersed in the rationality and the world of the other. More than comprehending the lifeworld and rethinking it in system form, the researcher dwells with the other and understanding emerges from that lived immersion. The other means of engaging are pagkaanaa or sensing the presence, panuluktuk or gaining insight through intuition, pamalandong or engaging in forms of contemplation to arrive at a deeper truth, pagtugyan or surrender to the experience and the spirits making themselves manifest, pagdawat or acceptance of the experience that is being given, and pag-agas or opening to the cosmos in a spirit-like flow are part of a larger process of sharing. Panagabyan is the process by which a person can meet the babaylan's abyan or spirit guide which will lead to an even deeper immersion into the diwata-filled world. This is accomplished, of course, by learning the songs and participating in rituals taught by the abyan, but also, being alert to and discerning of damgu (dreams), timala (signs), buna-buna (thoughts), and pagbati (feelings and sensations). ${ }^{14}$ These are spiritual, emotive, and relational ways of knowing that allow spirits to presence to us. In this way, the researcher is gifted by the babaylan, the community, and the spirits with a kind of knowing that is communal and participatory. The researcher enters into altered states and other rationalities that allow her to commune with nature, elders, spirits, and ancestors. In this methodology, the spirits and guides become co-researchers who are open to collaboration, if treated with respect. And if the researcher succeeds in entering the world of the babaylan and their abyan through these alternate methodologies, she will be able to explore a moral cosmos that is spirit-filled. She will get a glimpse of a world where our actions and our way of being conform to the cosmic order in which we are all responsible for each other. Because through discourse with spirits, we realize that individual good fortune and well-being is tied to the well-being and good fortune of others. It is a universe where knowledge and power are acquired through negotiation and communion. The arrival at the truth and understanding of the world is rooted in a kind of thinking that allows the human knower a communion with other knowers.

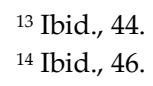

(c) 2019 Agustin Martin G. Rodriguez https://www.kritike.org/journal/special issue/rodriguez april2019.pdf ISSN 1908-7330

(c) BY-NC-ND 
At their core, these alternative research methods are means of preparing the researcher for an openness that does not aim at Western enframing. Rather, the researcher is made to open to the other in a kind of letting be: the letting be spoken to and taught to listen to other kinds of voices-including those of spirits; the letting be touched by reality in ways that defy one's conception of the logical and common sense. In other words, it is a research method that allows the researcher to open to the presencing of reality beyond what has been defined as legitimate knowledge. It is a method to access another world that presences to another rationality - a rationality which may potentially offer a way of seeing that enriches the dominant system. Researchers immersed in other common senses may be the only genuinely critical discourse partner of dominant rationalities.

\section{Towards a More Critical Critical Theory}

At this point, one may wonder why I am talking about such ideas for alternate research methods. Let us return to our concept of critical theory. Critical theory is a philosophical way of proceeding that allows people to unearth the ideologies that frame our social realities. It is a fruitful way of critiquing the growing influence of capitalism, the formation of global society, the new forms of enslavement of the economic actors, and the growing commodification of our relationships with the world and each other. With the various forms of ideology critique that unearthed the blinders that shaped the enframed self-realization of a supposedly enlightened and emancipated Western humanity, humanity was drawn to other forms of realizing Western rationalities without a radical critique of it. The process of ideology critique and emancipation from enslaving systems will always require the engagement of discourse partners who are genuinely other from the dominant system.

The Filipino scholar was never able to effectively develop a critical perspective from which to critique the dominant Western one. This is because, being trained in Western philosophizing, the Filipino scholar begins with the assumption that our traditional rationalities are, like capitalist and commodifying rationalities, unexamined frames for enslavement. Thus, immediately, the traditional, other rationality and its frame for being in the world are seen with suspicion because it also forms an ideology that can program people into destructive ways of being in the world. Thus, in academic circles, traditional worldviews are discredited as uncritical, unsystematic, and unable to liberate the colonized people from their oppression and the poor from their poverty. This, because of its alleged lack of sophistication and rigor. Every academic discipline needed to be accomplished in a systematic, Western frame of understanding, even the 


\section{A MORE CRITICAL CRITICAL THEORY}

most radical critiques of Western rationality, were not acceptable unless they took on the modes of thinking of Western systematic thinking.

This actually makes sense because the point of critical thinking is emancipation. As we stated, this emancipated person is a person who is an individual who can will the good by legislating for himself the ought. We can see how an uncritical use of critical theory, or any Western form of emancipatory thinking, can prejudice the discovery of the emancipatory discourse of other rationalities. This is because the means to understand the rationality of non-Western or traditional rationalities runs counter to the methods of an autonomous, critical, emancipated rationality. This is especially true because the traditional rationalities themselves are immediately understood to be counter-emancipatory. Fundamentally, the articulation of some alternative rationalities calls for the work of communal research grounded on the sympathetic opening to the world that is other than the dominant system. Thus, it is essential that we somehow achieve a kind of research methodology that does not completely serve the unconscious agenda of Westernization. Again, for a deep and radical critique of the dominant Western paradigm, we need categories of critique that do not serve to strengthen the imposition of dominant rationalities. This means we should cultivate a means to genuinely articulate our traditional rationalities.

This is what I mean by a more critical critical theory. We need to explore these "queer" ways of knowing other worlds because that is the only way we can challenge the dominant rationality to an extent that it can see its limits and possibilities from a perspective that is critical enough. But this demands that we build a new scholarship that allows marginalized rationalities to fairly discourse with the dominant one on their own terms.

Department of Philosophy, Ateneo de Manila University, Philippines

\section{References}

Almario, Virgilio, Ang Pag-ibig sa Bayan ni Andres Bonifacio (Manila: UST Publishing House, 2012). "Mga Bukal at Batis ng Nobelang Tagalog: Panimulang Suri," Unang Siglo ng Nobela sa Pilipinas (Manila: Anvil, 2009).

Asian Development Bank, The KALAHI-CIDSS Project in the Philippines: Sharing Knowledge on Community-Driven Development (Mandaluyong City: Asian Development Bank, 2012), <https://www.adb.org/sites/default/files/publication/ 29878/kalahicidss-project-philippines.pdf $>$.

(c) 2019 Agustin Martin G. Rodriguez

https://www.kritike.org/journal/special issue/rodriguez april2019.pdf

ISSN 1908-7330

(cc) BY-NC-ND 
Habermas, Jürgen, Between Facts and Norms: Contributions to a Discourse Theory of Law and Democracy, trans. by William Rehg (Cambridge: The MIT Press, 1999).

"Discourse Ethics: Notes on a Program of Philosophical Justification," Moral Consciousness and Communicative Action, trans. by Shierry Weber Nicholsen and Christian Lenhardt (Cambridge: The MIT Press, 1990).

"Remarks on Discourse Ethics," Justification and Application: Remarks on Discourse Ethics, trans. by Ciaran P. Cronin (Cambridge: The MIT Press, 1993).

"The European Nation-State: On the Past and Future of Sovereignty and Citizenship," in The Inclusion of the Other: Studies in Political Theory, ed. by Ciaran P. Cronin and Pablo De Greiff (Cambridge: The MIT Press, 2001).

The Theory of Communicative Action I, trans. by Thomas McCarthy (Boston: Beacon Press, 1984).

Ileto, Reynaldo, Pasyon and Revolution (Quezon City: Ateneo de Manila University Press, 1979).

Nono, Grace, Song of the Babaylan (Quezon City: Institute of Spirituality in Asia, 2013).

Salazar, Zeus, Ang Kartilya ni Emilio Jacinto at Ang Diwang Pilipino sa Agos ng Kasaysayan (Quezon City: Palimbag ng Lahi, 1999). 